POLISH JOURNAL OF SOIL SCIENCE

VOL. XLIX/2 $2016 \quad$ PL ISSN 0079-2985

DOI: $10.17951 / \mathrm{pjss} / 2016.49 .2 .209$

\title{
ANDRII BARANNYK, STEPAN POZNIAK* \\ NOMADIC TRANSFORMATION OF MOUNTAIN-MEADOW \\ BROWN SOILS (DYSTRIC CAMBISOLS) OF THE SVYDOVETS ARRAY OF THE UKRAINIAN CARPATHIANS
}

Received: 2016.11.15

Accepted: 2017.04.21

\begin{abstract}
In the highlands of the Ukrainian Carpathians, brown soil formation process is supplemented by turf, which significantly affects the soil properties and composition formation - this way unique shallow, rubble, highly acidic, base unsaturated, mountain-meadow brown soils with high $\mathrm{C}_{\text {org }}$ content (Dystric Cambisols) are formed. Irrational and haphazard farming in the valleys leads to the soil degradation and formation of specific anthropogenically altered mountain-meadow brown soil. To study the features of mountain-meadow brown soil formation and to analyze changes in properties, as a result of economic activity, we conducted detailed soil-geographic research within the valleys of the Svydovets array. Research has established that anthropogenically altered mountain-meadow brown soils are characterized by lower $\mathrm{C}_{\text {org }}$ rates, higher acidic reaction of the soil solution, high hydrolytic acidity and the dominance of exchange calcium in the absorbing soil complex, different qualitative humus composition - humate-fulvate. As a result of anthropogenic soil transformation, composition indicators underwent distinct changes - soil of the genetic horizons with a decrease in the total porosity; structure of the humus-accumulative horizon of virgin soil has undergone transformation and is characterized as prismoidal.
\end{abstract}

Keywords: nomadic transformation, mountain-meadow brown soils (Dystric Cambisols), Svydovets array, Ukrainian Carpathians

* Departament of Soil Science and Soil Geography, Ivan Franko National University of Lviv, Doroshenka St. 41, Lviv, 79000, e-mail: kfgeogrunt@franko.lviv.ua. Corresponding author: doctorant A. Barannyk. 


\section{INTRODUCTION}

Mountain-meadow soils are an independent and the most common type in the alpine zone of different mountain ranges forming under high humidity on various weathering products of different dense sedimentary and metamorphic rocks.

In the Ukrainian Carpathians, mountain-meadow soils occupy the highest position in the vertical zonation and are developed in the subalpine and alpine zones under the dense grassy vegetation, where in the cold climates two bioclimatic zones are clearly distinguished: alpine and subalpine differing by nature vegetation.

Despite a fairly large number of works devoted to mountain-meadow soils, soil formation peculiarities occurring there are insufficiently studied and classifications of mountain soil of Ukraine cannot be considered satisfactory. That is why the issue of peculiarities of mountain soil formation remains controversial. At the same time, peaks and slopes soils are intensively involved in the economic activities. Therefore, the issue of mountain soil formation specificity, peculiarities of soil cover differentiation in the mountains and analysis of changes in the soil properties due to economic activity is relevant.

The aim of the article is to examine the features of mountain-meadow brown soils formation and analysis of changes in their properties, as a result of economic activity.

\section{STUDY AREA}

The Svydovets is a mountain range, one of the backbone elements of ancient glacial-subalpine meadow flysch landscapes of the Ukrainian Carpathians (Fig. 1). The most elevated part of the Svydovets landscape is the main Svydovets ridge that is of a convex shape to the north-east of the mountain arc passing through the peaks: Kinets $(1,308 \mathrm{~m})$, Tatuliaska $(1,774 \mathrm{~m})$ and Blyznytsia $(1,883 \mathrm{~m})$.

The upper forest boundary of the Svydovets array is spruce and beech forests which on average are located at an altitude of 1,400 $\mathrm{m}$ above sea level. The solid spruce forests rise up to an average altitude of 1,320 m. On the southern Svydovets macroslope, beech grows to an altitude of 1,380 $\mathrm{m}$ above sea level. This is the highest limit for beech in the Ukrainian Carpathians. Above the upper forest boundary, there is mountain-meadow zone (Fig. 1). It covers the area confined to the subalpine and alpine zones located on the flat peaks of the mountains and their slopes at an altitude of 1,300-1,400 m above sea level (Baytsar 2015).

In the Ukrainian Carpathians, mountain-meadow zone whose area is over 55 thousand ha (Polupan et al. 2006) does not form a solid array, and lies in the form of separate areas, also known as subalpine meadow (polonyna). A large number of meadows is confined to the Svydovets array. The soil cover is represented mainly 


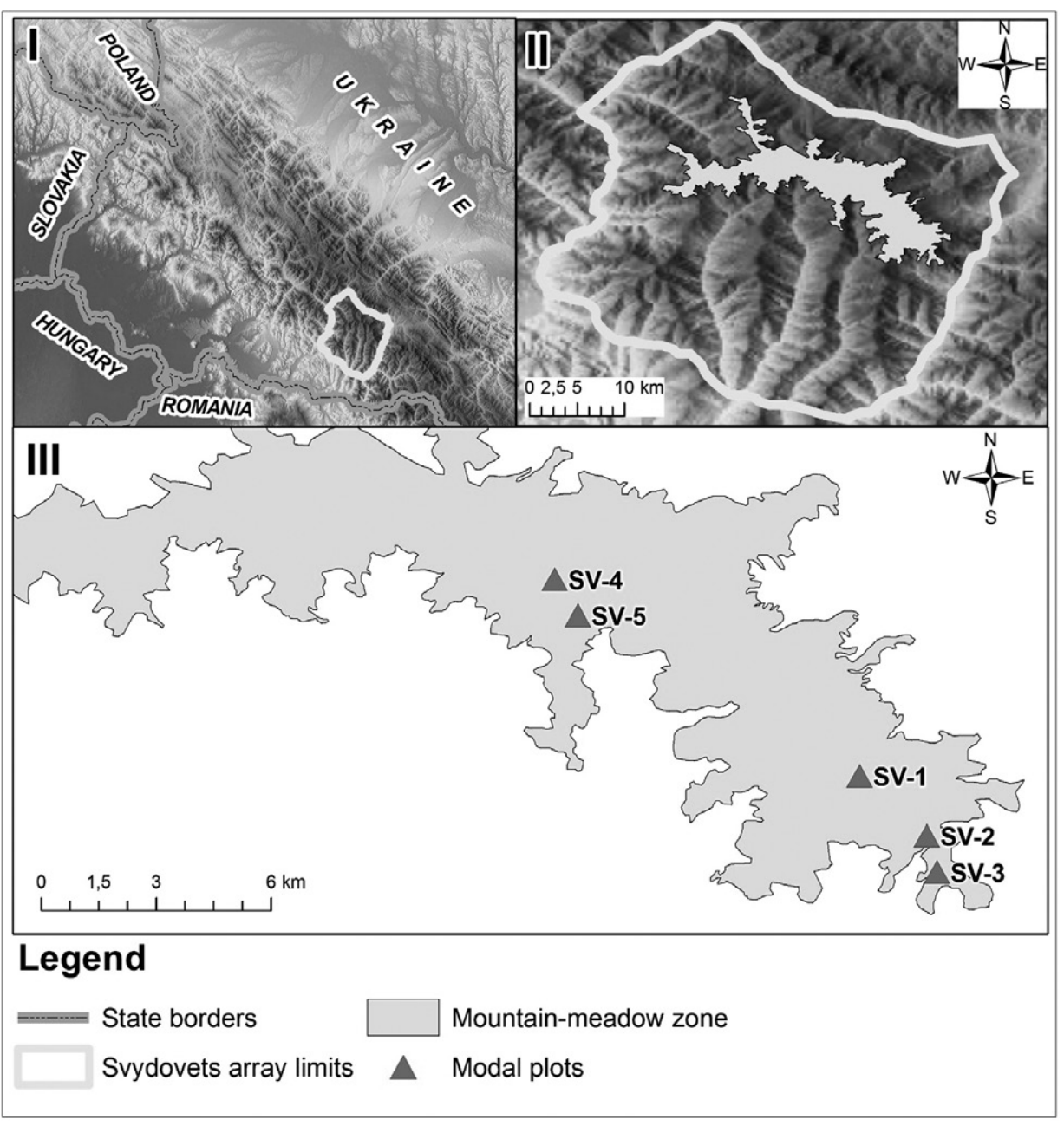

Fig. 1. Location (I) and topography (II) of the study site, location of modal plots (III).

by mountain-meadow brown soils. The name most accurately reflects the genetic nature of the soil emphasizing their forest origin in the past, as evidenced by the structure profiles and physicochemical properties identical to the brown forest soils of mountain forest zone. On the other hand, this title covers modern soil processes occurring under the canopy of meadow vegetation (Gogolev 1961, 1965).

\section{MATERIAL AND METHODS}

The study of mountain meadow zone soil of the Ukrainian Carpathians is always held in conjunction with the study of other types of brown soils of different soil and climatic zones. Particular attention was first paid to the study of meadow 
soils by the Ukrainian investigators. Physico-chemical properties and characteristics of mineralogical and gross chemical composition were in detail highlighted in the works of I. M. Gogolev, V. I. Kanivets, P. S. Pasternak, S. P. Pozniak and others (Barannyk 2014-2016; Barannyk, Pozniak 2015; Gogolev 1961, 1965; Kanivets 1978, 2012; Pozniak 2002; Polupan et al. 2006). In recent years, interest in the nature of the Ukrainian Carpathians has increased, which helped activate Polish soil science research in the area (Chodorowski et al. 2003; Skiba et al. 1997; Skiba, Drewnik 2003; Skiba, Pozniak 2006; Skiba, Szmuc 1998).

To study the characteristics of formation, the differences in the composition and properties of mountain-meadow brown soil formed on the products of Carpathian flysch weathering in the highlands within the Svydovets array, we have carried out detailed soil study at different hypsometric levels in different bioclimatic zones: the alpine and subalpine and in place of intensive grazing (sheep pen) to study the transformation of virgin soil under the economic activity in the meadows.

Details of the modal sections are presented in Table 1.

\section{TABLE 1. GENERAL DESCRIPTION OF MODAL SECTIONS WITHIN THE HIGHLANDS OF SVYDOVETS ARRAY}

\begin{tabular}{|c|c|c|c|c|c|}
\hline $\begin{array}{l}\text { No. of } \\
\text { the modal } \\
\text { section }\end{array}$ & $\begin{array}{l}\text { Soil } \\
\text { cut }\end{array}$ & Peak, meadow & $\begin{array}{l}\text { Altitude } \\
\text { asl }\end{array}$ & $\begin{array}{l}\text { Bioclimatic } \\
\text { zone }\end{array}$ & Coordinates \\
\hline No. 1 & SV-1 & Fringes of Blyznytsia peak & $1,880 \mathrm{~m}$ & Alpine & $48^{\circ} 12^{\prime} 59^{\prime \prime} \mathrm{N} 24^{\circ} 14^{\prime} 13^{\prime \prime} \mathrm{B}$ \\
\hline No. 2 & SV-2 & Stremcheska meadow & $1,420 \mathrm{~m}$ & \multirow{4}{*}{ Subalpine } & $48^{\circ} 11^{\prime} 46^{\prime \prime} \mathrm{N} 24^{\circ} 15^{\prime} 29^{\prime \prime} \mathrm{B}$ \\
\hline No. 3 & SV-3 & $\begin{array}{l}\text { Breska meadow (sheep } \\
\text { pen) }\end{array}$ & $1,328 \mathrm{~m}$ & & $48^{\circ} 11^{\prime} 17^{\prime \prime} \mathrm{N} 24^{\circ} 15^{\prime} 18^{\prime \prime} \mathrm{E}$ \\
\hline No. 4 & SV-4 & Vedeniaska meadow & $1,405 \mathrm{~m}$ & & $48^{\circ} 15^{\prime} 21^{\prime \prime} \mathrm{N} 24^{\circ} 11^{\prime} 43^{\prime \prime} \mathrm{E}$ \\
\hline No. 5 & SV-5 & $\begin{array}{l}\text { Vedeniaska meadow } \\
\quad \text { (sheep pen) }\end{array}$ & $1,347 \mathrm{~m}$ & & $48^{\circ} 15^{\prime} 16^{\prime \prime} \mathrm{N} 24^{\circ} 10^{\prime} 52^{\prime \prime} \mathrm{E}$ \\
\hline
\end{tabular}

In the selected soil samples of fine earth, using conventional methods, the following was identified: 1) the absorbing moisture - by thermostat-gravimetric method (drying at $105^{\circ} \mathrm{C}$ ); 2) structure density - by drilling method; 3) solids density - by pycnometer method; 4) fine earth grain size - by Kachynskyi's method with soil preparation by pyrophosphate method (ISO 4728: 2007); 5) $\mathrm{pH}(\mathrm{KCl})$ - potentiometrically at $\mathrm{pH}-$ meter (pH-150m) (ISO 10390: 2005); 6) hydrolytic acidity - by Kappen method modified by Central Scientific Research Institute of Agrochemical Service (ISO 26212-91); 7) $\mathrm{C}_{\text {org }}$ - the Turin method modified by Simakov (ISO 14235: 1998); 8) exchangeable base cations (Ca, $\mathrm{Mg}$ ) extracted by ammonium acetate complex-metric method (ISO 26487-85); aluminum and hydrogen - by Sokolov's method; 9) group and fractional composition of humus - the Turin method modified by Ponomareva and Plotnikova (ISO 4289: 2004). 


\section{RESULTS AND DISCUSSION}

Haphazard, inefficient use of mountain pastures leads to their degradation. With increase in the anthropogenic pressure, following stages change: destruction of vegetation; destruction of soil; destruction of lithosphere. Ecologically unlimited meadows development leads to the intensification of degradation processes and the formation of specific anthropogenically altered mountain-meadow brown soils that differ in their properties and qualities from the virgin ones (Fig. 2).
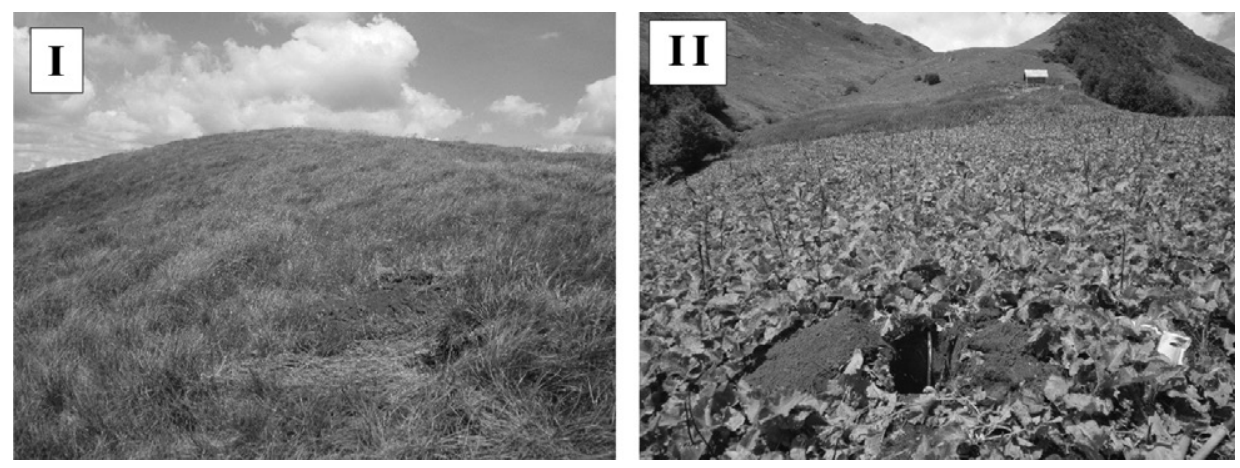

Fig. 2. Meadows with integral (I) and anthropogenically altered (II) phytocoenoses

Morphological features of genetic horizons give an idea of the nature of regimes that define the modern processes of soil genesis (Pozniak 2002).

The genetic profile of mountain-meadow brown soil is shallow, rubble and undifferentiated on eluvio-illuvial horizons. In soils formed under well-developed herbaceous vegetation, a large capacity $(5-7 \mathrm{~cm})$ turf humus-accumulative horizon (A1) is formed. Under the influence of the turf process, strong (12-16 $\mathrm{cm}$ ) humus horizon was formed (A2), dark in color, rich in organic remains and nutrients with strong waterproof granular structure. A characteristic feature of mountain-meadow brown soil is high rubble content of the entire genetic profile. Soil skeleton on the soil surface acts as a "protective shell" and prevents water erosion, while intrasoil skeleton forms favorable water-air properties of genetic horizons (Fig. 3). Under the influence of human activities (intensive grazing) distinct changes in the structure of the genetic profile of soils took place. There is no turf horizon in the anthropogenically altered soil due to a change in the vegetation of virgin grassland to horse sorrel (Rumex confertus), which does not form a turf (Fig. 2). The upper humus-accumulative horizon (A) of the anthropogenically altered soil is characterized by dense composition and is more humid, as compared to the same horizon of virgin soil, due to a change in vegetation (alpine grasses were replaced by horse sorrel), and, in fact, soil turnover processes. The transition between the humus-accumulative (A) and upper transition horizons (B) is less vivid. 
Soil profile $\mathrm{SV}-1$

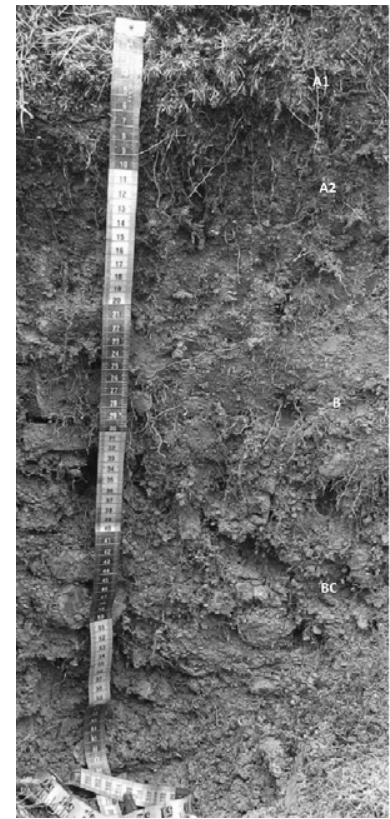

Soil profile $\mathrm{SV}-4$

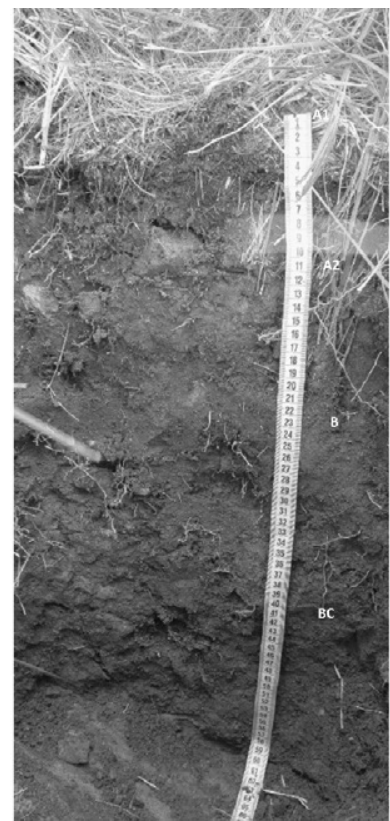

Soil profile $\mathrm{SV}-5$

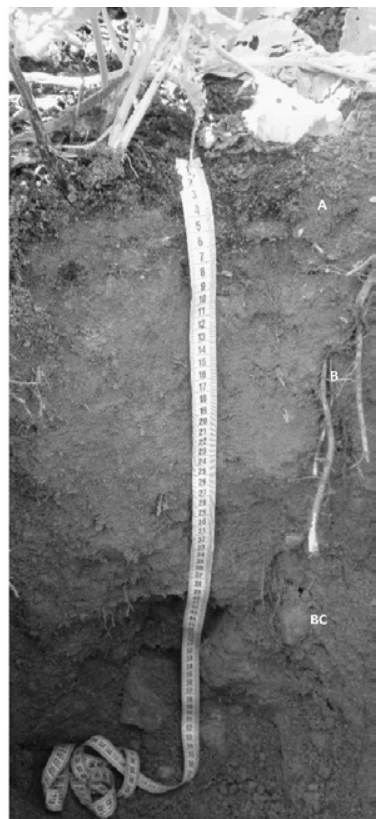

Fig. 3. Morphological structure of alpine (SV-1), subalpine (SV-4) and anthropogenically altered (SV-5) profile of the mountain-meadow brown soil

Since the formation conditions of mountain-meadow soils are very wet climate and the washing type of water regime, this promotes bases leaching out of the soil profile. Due to the lack of neutralizing cations, plant residues decompose to form corrosive organic acids. Therefore, most indicators are confined to acidity and humus horizon A, the bottom layer of turf and soil acidity naturally decreases down the profile. Alpine zone soils are more acidic due to the large concentration of aluminum-hydrogen exchange (Table 2). It should be noted that the strong acidity of soil solution does not result in podzol formation. Mountain-meadow brown soils of the Svydovets array are leached, base unsaturated (degree of saturation is less than 10\%), with soil solution acidic reaction $\left(\mathrm{pH}_{\mathrm{KCl}}\right.$ less than 4.5) (Table 2).

According to research I. Gogolev, $\mathrm{pH}_{\mathrm{KCl}}$ of the humus-accumulative horizon brown soils is 3.6-4.0. In the lower layers of brown soil value of $\mathrm{pH}_{\mathrm{KCl}}$ increased and is characterized as (Gogolev 1961, 1965). Exchange acidity of brownsoils almost exclusively caused by the presence of aluminum cations. Only in the upper humus-accumulative horizons exchange acidity determined by the concentration of hydrogen ions (Gogolev 1961, 1965).

According to V. Kanivets, brown soils of the Ukrainian Carpathians are characterized as highly acidic soils. They have highly acidic reaction $\left(\mathrm{pH}_{\mathrm{H} 2 \mathrm{O}}-\right.$ 4.8-4.6 and below). In brown soils is a process of acid hydrolysis aluminosilicate, accumulated a significant number of mobile (exchange) aluminum, result- 
ing from the specific microorganisms transform organic residues. Saturation of colloidal complex with aluminum - the result of biological processes of brunification (Kanivets 1978, 2012).

TABLE 2. CHEMICAL AND PHISICOCHEMICAL PROPERTIES OF MOUNTAIN-MEADOW BROWN SOILS (DYSTRIC CAMBISOLS)

\begin{tabular}{|c|c|c|c|c|c|c|c|c|c|}
\hline \multirow{3}{*}{$\begin{array}{l}\text { Genetic } \\
\text { horizon }\end{array}$} & \multirow{3}{*}{$\begin{array}{c}\text { Depth } \\
{[\mathrm{cm}]}\end{array}$} & \multirow{3}{*}{$\mathrm{pH}_{\mathrm{KCl}}$} & \multirow{3}{*}{$\begin{array}{l}\mathrm{C}_{\text {org }} \\
{[\%]}\end{array}$} & \multirow{3}{*}{$\begin{array}{c}\begin{array}{c}\text { Hydrolytic } \\
\text { acidity }\end{array} \\
{[\mathrm{mmol} / 100 \mathrm{~g}} \\
\text { of the soil }]\end{array}$} & \multirow{3}{*}{ 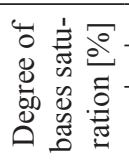 } & \multicolumn{4}{|c|}{ Exchangeable cations } \\
\hline & & & & & & $\mathrm{Ca}^{2+}$ & $\mathrm{Mg}^{2+}$ & $\mathrm{Al}^{3+}$ & $\mathrm{H}^{+}$ \\
\hline & & & & & & \multicolumn{4}{|c|}{$[\mathrm{mmol} / 100 \mathrm{~g}$ of the soil $]$} \\
\hline \multicolumn{10}{|c|}{ Mountain-meadow brown alpine soil on eluvium-delluvial of the Carpathian flysch (cut SV-1) } \\
\hline $\mathrm{H}(\mathrm{A} 2)$ & $5-20$ & 3.42 & 9.64 & 34.48 & 4.83 & 3.50 & 2.50 & 12.00 & 1.33 \\
\hline $\mathrm{Hp}(\mathrm{B})$ & $21-36$ & 3.66 & 4.33 & 24.19 & 6.02 & 3.00 & 1.50 & 8.40 & 0.70 \\
\hline $\mathrm{Ph}(\mathrm{BC})$ & $37-54$ & 4.00 & 1.63 & 11.67 & 9.25 & 2.50 & 0.50 & 3.20 & 0.10 \\
\hline
\end{tabular}

Mountain-meadow brown subalpine soil on eluvium-delluvial of the Carpathian flysch (cut SV-2)

\begin{tabular}{cccccccccc}
\hline $\mathrm{H}(\mathrm{A} 2)$ & $6-26$ & 3.56 & 3.96 & 21.86 & 5.85 & 4.00 & 1.50 & 8.90 & 0.70 \\
\hline $\mathrm{Hp}(\mathrm{B})$ & $27-50$ & 3.74 & 2.42 & 15.82 & 6.94 & 3.25 & 0.75 & 7.40 & 0.20 \\
\hline $\mathrm{Ph}(\mathrm{BC})$ & $51-79$ & 4.00 & 1.26 & 11.31 & 7.29 & 2.75 & 0.75 & 4.50 & 0.10 \\
\hline
\end{tabular}

Mountain-meadow brown subalpine anthropogenically altered soil on eluvium-delluvial of the Carpathian flysch (cut SV-3)

\begin{tabular}{cccccccccc}
\hline $\mathrm{H}(\mathrm{A})$ & $0-23$ & 3.16 & 3.68 & 24.19 & 5.58 & 7.50 & 2.50 & 4.45 & 0.75 \\
\hline $\mathrm{Hp}(\mathrm{B})$ & $24-48$ & 3.81 & 1.80 & 15.28 & 6.02 & 4.50 & 2.00 & 3.73 & 0.27 \\
\hline $\mathrm{Ph}(\mathrm{BC})$ & $49-67$ & 4.17 & 1.49 & 10.67 & 6.90 & 4.00 & 2.00 & 3.15 & 0.15 \\
\hline
\end{tabular}

Mountain-meadow brown subalpine soil on eluvium-delluvial of the Carpathian flysch (cut SV-4)

\begin{tabular}{cccccccccc}
\hline $\mathrm{H}(\mathrm{A} 2)$ & $6-22$ & 3.53 & 4.01 & 21.20 & 6.32 & 4.10 & 1.50 & 9.00 & 0.85 \\
\hline $\mathrm{Hp}(\mathrm{B})$ & $23-35$ & 3.68 & 2.65 & 16.78 & 6.78 & 3.50 & 1.25 & 8.35 & 0.25 \\
\hline $\mathrm{Ph}(\mathrm{BC})$ & $36-60$ & 3.84 & 1.43 & 12.31 & 7.37 & 3.00 & 1.00 & 4.75 & 0.15 \\
\hline
\end{tabular}

Mountain-meadow brown subalpine anthropogenically altered soil on eluvium-delluvial of the Carpathian flysch (cut SV-5)

\begin{tabular}{cccccccccc}
\hline $\mathrm{H}(\mathrm{A})$ & $0-17$ & 3.13 & 3.72 & 23.98 & 5.40 & 6.50 & 3.50 & 5.00 & 0.70 \\
\hline $\mathrm{Hp}(\mathrm{B})$ & $18-40$ & 3.62 & 2.46 & 14.28 & 6.54 & 5.50 & 2.00 & 4.25 & 0.20 \\
\hline $\mathrm{Ph}(\mathrm{BC})$ & $41-68$ & 4.08 & 1.55 & 11.67 & 6.56 & 4.00 & 1.75 & 3.00 & 0.10 \\
\hline
\end{tabular}

Under the influence of anthropogenic factors, soil solution is acidified and the share of exchange calcium in the absorbing complex is increasing, reflecting a change in vegetation and heavy influence of radical horse sorrel discharge (Rumex confertus) with respect to the mineral part of the soil. In our view, increased exchange of calcium in anthropogenically altered soils caused by biological factors: change of ash plants, permanent ones flow of calcium compounds from manure of animals. Sheep manure has increased content of calcium compounds - up to $0.50 \%$ of the total weight. Increased acidity of the soil does not manage to neutralize the calcium compounds due to its a permanent flow of soil mass (Barannyk 2014; Barannyk, Pozniak 2015). 
It should be noted that anthropogenically altered soil is characterized by lower $\mathrm{C}_{\text {org }}$ content than subalpine virgin soil. This fact is explained by several reasons: firstly, because of intensive grazing on pastures turf soil horizon was completely destroyed and mixed with lower humus-accumulative horizon; secondly, productive plant communities of the virgin subalpine meadows, consisting mainly of Juncus triglumis L., Deschampsia caespitosa (tufted hairgrass), Festuca pratensis (meadow fescue), have been replaced by unproductive horse sorrel (Rumex confertus).

According to our research, humus of mountain-meadow brown soils is characterized by a fulvic acid predominance over humic acid - the $\mathrm{C}_{\mathrm{HA}}: \mathrm{C}_{\mathrm{FA}}$ ratio varies from $0.30-0.55$ in the upper humus horizon; high mobility of humic acids, very low density (Table 3 ). The narrowing of $\mathrm{C}_{\mathrm{HA}}: \mathrm{C}_{\mathrm{FA}}$ ratio in the lower horizons is mainly due to the increase of fulvic acid content, while humic acid content throughout the soil profile remains relatively stable. Soil humus is characterized by high solubility of humic substances associated with low exchange calcium content and the predominance of fulvic acid (Barannyk 2016).

During the anthropogenic changes of soil under the influence of intensive grazing, qualitative humus content acquired properties other than those of virgin soil humus. The content of humic acid almost doubled in the upper humus, and the content of fulvic acid group 1 fraction exceeds normal parameters. High "aggressiveness" of humic acids of the anthropogenically altered soils determines their high acidity, as compared to virgin soils of the subalpine zone (Barannyk 2016).

I. Gogolev's researches of humus showed, that brow nsoils enriched hydrolyzed nitrogen, and group and fractional composition of humus of brow nsoils not significantly different with changing of vegetation. Fulvic acid dominates over the humic acids (Gogolev 1961, 1965). Researches showed, that humus composition determined by the height above sea level, vegetation composition and properties of parent material (Kanivets 1978, 2012).

TABLE 3. FRACTIONAL AND GROUP COMPOSITION OF HUMUS OF MOUNTAIN-MEADOW BROWN SOILS (DYSTRIC CAMBISOLS)

\begin{tabular}{|c|c|c|c|c|c|c|c|c|c|c|c|c|c|}
\hline \multirow{3}{*}{$\begin{array}{l}\overrightarrow{0} \\
\overline{0} \\
\ddot{\circ}\end{array}$} & \multirow{3}{*}{ 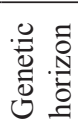 } & \multicolumn{4}{|c|}{ Humic acids [\%] } & \multicolumn{5}{|c|}{ Fulvic acids [\%] } & \multirow{3}{*}{ 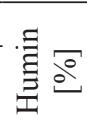 } & \multirow{3}{*}{$\begin{array}{l}U^{\mathbb{4}} \\
\cdots \\
U^{\rrbracket}\end{array}$} & \multirow{3}{*}{ 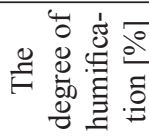 } \\
\hline & & \multicolumn{3}{|c|}{ Fractions } & \multirow{2}{*}{$\Sigma$} & \multicolumn{4}{|c|}{ Fractions } & \multirow{2}{*}{$\Sigma$} & & & \\
\hline & & 1 & 2 & 3 & & 1a & 1 & 2 & 3 & & & & \\
\hline \multirow{2}{*}{$\frac{T}{n}$} & A2 & 12.37 & - & 1.13 & 13.50 & 5.40 & 11.00 & 2.10 & 7.00 & 25.50 & 61.00 & 0.53 & 13.50 \\
\hline & B & 11.00 & - & 2.00 & 13.00 & 9.50 & 17.00 & 3.50 & 12.00 & 42.00 & 45.00 & 0.31 & 13.00 \\
\hline \multirow{2}{*}{$\frac{T}{i}$} & A2 & 10.87 & - & 1.76 & 12.63 & 9.21 & 12.23 & 3.58 & 11.15 & 36.17 & 51.20 & 0.35 & 12.63 \\
\hline & B & 9.60 & - & 2.10 & 11.70 & 15.80 & 19.65 & 5.54 & 17.11 & 58.10 & 30.20 & 0.20 & 11.70 \\
\hline \multirow{2}{*}{$i_{n}^{n}$} & A & 18.46 & - & 6.13 & 24.59 & 6.12 & 19.46 & 3.98 & 8.72 & 38.28 & 37.13 & 0.64 & 24.59 \\
\hline & B & 7.42 & - & 2.00 & 9.42 & 11.17 & 13.45 & 2.78 & 8.53 & 35.93 & 54.65 & 0.26 & 9.42 \\
\hline
\end{tabular}


Granulometric composition of soils is largely inherited from the soil forming rocks and in terms of the main features is similar to that of the soil. It reflects the soil forming rocks genesis, indicates the direction of their change in the soil formation.

\section{TABLE 4. GRANULOMETRIC COMPOSITION OF THE FINE EARTH OF THE MOUNTAIN-MEADOW BROWN SOILS}

\begin{tabular}{|c|c|c|c|c|c|c|c|c|}
\hline \multirow{2}{*}{ 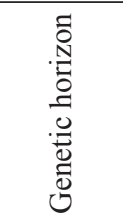 } & \multirow[b]{2}{*}{ 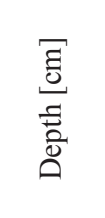 } & \multicolumn{6}{|c|}{ The particle size $[\mathrm{mm}]$, number [\%] } & \multirow[b]{2}{*}{ 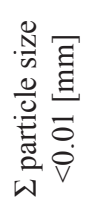 } \\
\hline & & 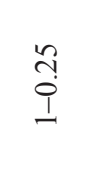 & 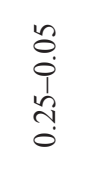 & $\begin{array}{l}\overrightarrow{0} \\
0 \\
0 \\
2 \\
0 \\
0\end{array}$ & 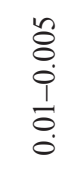 & 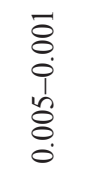 & $\begin{array}{l}\overrightarrow{8} \\
\dot{8} \\
\dot{v}\end{array}$ & \\
\hline \multicolumn{9}{|c|}{ Mountain-meadow brown alpine soil on eluvium-delluvial of the Carpathian flysch (cut SV-1) } \\
\hline $\mathrm{H}(\mathrm{A} 2)$ & $5-20$ & 12.99 & 19.41 & 22.70 & 6.19 & 20.62 & 18.12 & 44.92 \\
\hline $\mathrm{Hp}(\mathrm{B})$ & $21-36$ & 11.96 & 19.50 & 22.70 & 6.19 & 20.62 & 19.06 & 45.86 \\
\hline $\mathrm{Ph}(\mathrm{BC})$ & $37-54$ & 12.04 & 22.16 & 22.50 & 6.12 & 18.37 & 18.86 & 43.35 \\
\hline \multicolumn{9}{|c|}{ Mountain-meadow brown subalpine soil on eluvium-delluvial of the Carpathian flysch (cut SV-4) } \\
\hline $\mathrm{H}(\mathrm{A} 2)$ & $6-22$ & 11.03 & 26.43 & 16.49 & 10.31 & 19.59 & 16.15 & 46.05 \\
\hline Hp (B) & $23-35$ & 12.68 & 27.46 & 14.43 & 6.19 & 20.62 & 18.62 & 45.42 \\
\hline $\mathrm{Ph}(\mathrm{BC})$ & $36-60$ & 15.26 & 33.63 & 14.43 & 4.12 & 14.43 & 18.12 & 36.68 \\
\hline \multicolumn{9}{|c|}{$\begin{array}{c}\text { Mountain-meadow brown subalpine anthropogenically altered soil on eluvium-delluvial of the } \\
\text { Carpathian flysch (cut SV-5) }\end{array}$} \\
\hline $\mathrm{H}(\mathrm{A})$ & $0-17$ & 8.04 & 33.51 & 6.19 & 10.31 & 25.77 & 16.18 & 52.26 \\
\hline $\mathrm{Hp}(\mathrm{B})$ & $18-40$ & 9.9 & 27.80 & 16.49 & 6.19 & 20.62 & 19.00 & 45.80 \\
\hline $\mathrm{Ph}(\mathrm{BC})$ & $41-68$ & 11.96 & 30.77 & 8.25 & 8.25 & 22.68 & 18.09 & 49.02 \\
\hline
\end{tabular}

Almost all natural, mostly physical-chemical and chemical properties of soils and their regimes depend on it. It is important that the granulometric composition determines the structural levels of the solid phase formation and is directly involved in the formation of micro and macrostructure and largely determines its structural and functional properties. The proportion in the distribution of elementary soil particles throughout fractions and their properties significantly affect both the aggregate level, and the nature of the porosity dynamics.

Fractions of the granulometric elements of the fine earth prevailing in the mountain-meadow brown soils are fine sand (particle diameter $0.25-0.05 \mathrm{~mm}$ ) and large $(0.05-0.01 \mathrm{~mm})$ and fine $(0.005-0.001 \mathrm{~mm})$ silt. The overall trend to decrease in the content of clay (particle diameter less than $0.001 \mathrm{~mm}$ ) in alpine zone soil was observed (Table 4). Minor and average loamy soils are more common in the alpine bioclimatic zone, where they are usually confined to the crust of massive crystalline rocks weathering. The presence of a significant amount of physical clay $(<0.01 \mathrm{~mm})$ in the fine earth of mountain-meadow brown soils indicates a significant role of chemical weathering along with the physical one, in the soil formation.

Within the human activities, under the influence of intensive grazing grain size of mountain-meadow brown soils has not undergone distinct changes (Barannyk 2015). 
According to I. Gogolev's researches, granulometric composition of the fine earth of brown soils of the Ukrainian Carpathians applies to medium and heavy loam, due to features of parent material. There is a direct correlation of soil particle size distribution of dominance components of flysch sandstone or shale (siltstones and argillite) (Gogolev 1961, 1965). Research conducted by V. Kanivets show, that soils under forest and meadow vegetation features have the same grain size (Kanivets 1978, 2012).

Soil, as any natural body, is characterized by a number of physical properties whose variability may be explained by the peculiarities of soil forming rocks, age, soil forming processes, intensity and nature of soil use in the economic activity. The natural factors of general physical properties differentiation include: content and quality of the mineral and organic substances in the soil, structural condition, vegetation, etc. Soil density and porosity are expressed in soil composition. Integrated indicators that define the soil content include: solid phase density, structure density, total porosity.

\section{TABLE 5. PHYSICAL PROPERTIES OF MOUNTAIN-MEADOW BROWN SOILS} (DYSTRIC CAMBISOLS)

\begin{tabular}{ccccc}
\hline Genetic horizon & $\begin{array}{c}\text { Depth } \\
{[\mathrm{cm}]}\end{array}$ & $\begin{array}{c}\text { Particle density } \\
{\left[\mathrm{g} / \mathrm{cm}^{3}\right]}\end{array}$ & $\begin{array}{c}\text { Bulk density } \\
{\left[\mathrm{g} / \mathrm{cm}^{3}\right]}\end{array}$ & $\begin{array}{c}\text { Soil porosity } \\
{[\%]}\end{array}$ \\
\hline Mountain-meadow brown alpine soil on eluvium-delluvial of the Carpathian flysch (cut SV-1) \\
\hline H (A2) & $5-20$ & 2.03 & 0.84 & 58.62 \\
\hline Hp (B) & $21-36$ & 2.27 & 0.99 & 56.39 \\
\hline Ph (BC) & $37-54$ & 2.43 & 1.11 & 54.51 \\
\hline Mountain-meadow brown subalpine soil on eluvium-delluvial of the Carpathian flysch \\
(cut SV-2)
\end{tabular}


Density of the solid phase of the studied soils varies within a narrow range of values and naturally increases down the profile due to the close links with the source rock, undifferentiated profile in terms of granulometric content, absence of stratification signs in the profile and reduction in the organic soil mass with depth. In the humus-accumulative horizon (A2) of the mountain-meadow brown soils, solid phase density is the lowest and gradually increases reaching its maximum at the lower transition horizon (BC). Increase in parameters down the soil profile is correlated with the decrease in the number of $\mathrm{C}_{\text {org }}$ in the same direction and uniform growth in the terrigenous material (Table 5).

Study findings indicate no significant changes in the density of the solid phase of mountain-meadow brown soils under the influence of anthropogenic activity. This conclusion is logical, as the analysis of particle size distribution revealed no significant changes in the redistribution of elementary soil particles fractions.

The structure density is one of the most important physical characteristics of the soil, which influences their water, air and thermal regimes. Studies have shown that the average values of the structure density in the upper humus-accumulative horizon (A2) vary from $0.84-1.10 \mathrm{~g} / \mathrm{cm}^{3}$ and characterized by a very loose, and this parameter is gradually increasing with depth down the profile. This phenomenon is primarily due to the decrease of organic matter content down the profile. Structure density of the genetic horizons of the anthropogenically altered soil is significantly higher resulting from the destruction of the structure and change in its forms. This cumulative compaction is caused by a long trampling on the soil and over-compaction. Indicators of the structure density in the upper humus-accumulative horizon increased to $1.20 \mathrm{~g} / \mathrm{cm}^{3}$, and in the transition horizon - up to $1.50 \mathrm{~g} / \mathrm{cm}^{3}$ (Table 5).

In mountain-meadow brown soils with uniform granulometric composition, porosity is a function of the structure density. Therefore, with the increase in the soil structure density, total porosity is naturally reducing. Variability of the overall porosity in the upper humus-accumulative horizon (A2) of the mountain-meadow brown soils is narrowed and amounts to 51.85-58.62\%. Down the profile, parameters decrease to $37.87-54.51 \%$ due to the decrease in the $\mathrm{C}_{\text {org }}$ content in the same direction. The essential feature of the anthropogenically altered soils is soil compacting with the decrease in the overall porosity (Table 5) (Barannyk 2015).

The structural condition of mountain-meadow brown soils is characterized by the dominance of granular, finely lumpy structure with distinct correct form of aggregates. Under the influence of the anthropogenic factor, structure of the soils humus-accumulative horizon underwent transformation and is characterized by prismoidal structure with a predominance of well defined prismatic and block structures. As a result of soil horizon over-compaction under soil turnover processes, block faction was formed characterized by high structure density (Fig. 4) (Barannyk 2015). 


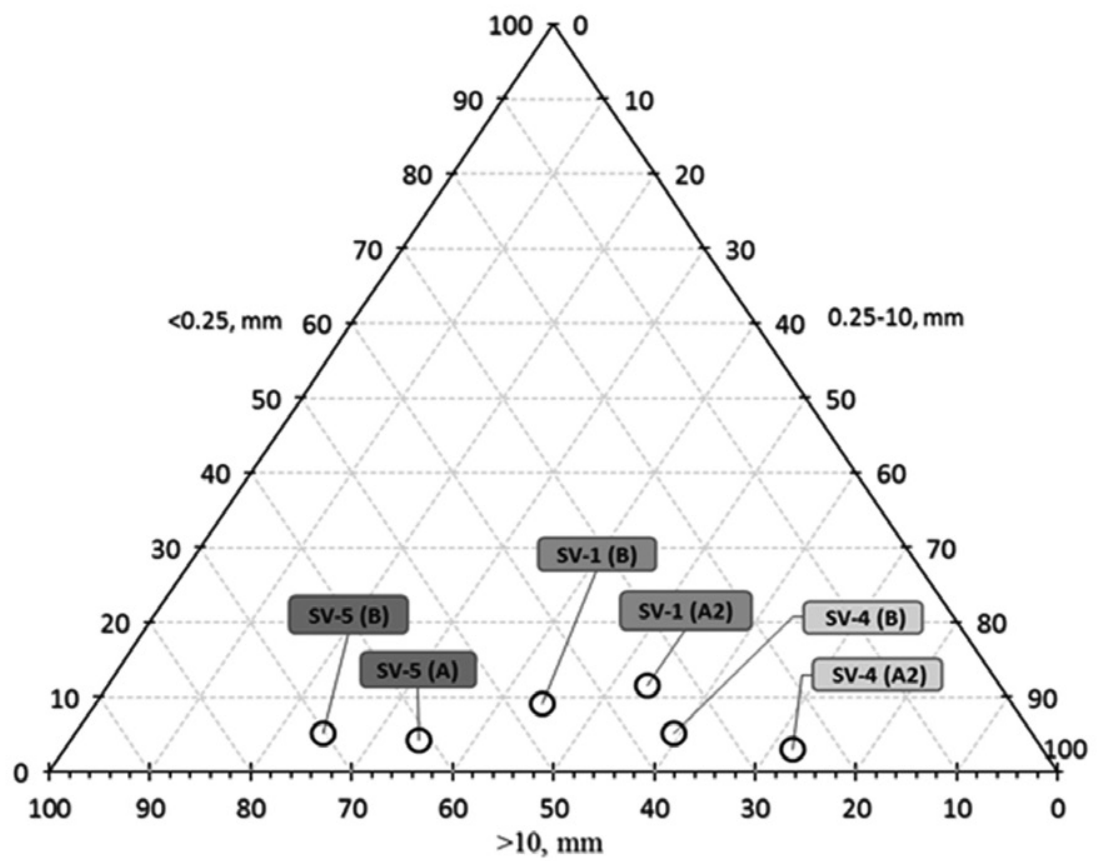

Fig. 4. Structural-aggregate composition of mountain-meadow-brown soil

An important feature of the soil structure is its water resistance manifested through the ability of structural aggregates to resist the damaging effects of water for a long time. The stability of soil aggregates depends on the humus quality and availability of irreversibly coagulated organic and mineral colloids in the soil which determine the granulometric elements cementation. Evaluation of the macrostructure water resistance of mountain-meadow brown soils showed that soil aggregates in the upper humus-accumulative horizon have excessively high water resistance - the amount of waterproof aggregates with the size of $>0.25 \mathrm{~mm}$ is over $75 \%$.

Thus, we can conclude that the structure of mountain-meadow soils is strong, which is especially important for the washing soils of water regime.

Analysis of the study findings of the aggregation composition of mountain-meadow brown soils on the study site gives reason to believe that in the formation of soil profile, in genetic horizons, strong, well defined, granular, fine lumpy, water resistant structure is formed. It is under the influence of human activity that agronomically valuable aggregates are destroyed and smaller particles are glued to the prismoidal aggregates. 


\section{CONCLUSIONS}

1. In the highlands of the Svydovets array of the Ukrainian Carpathians under the canopy of the alpine and subalpine grassy vegetation combined with a brown soil type of soil formation, specific shallow, rubbly highly acid, base unsaturated, humus-rich mountain-meadow brown soils are formed. Brown soil formation under herbaceous vegetation is due to the high humidity climate and drainage conditions of the soil forming rocks.

2. Environmentally unlimited development of meadows leads to the intensification of degradation processes and the formation of specific anthropogenically altered mountain-meadow brown soils that differ in their properties and qualities from the virgin soils.

3. Anthropogenically altered mountain-meadow brown soils are characterized by lower $\mathrm{C}_{\text {org }}$ content, higher acidic soil solution reaction, high hydrolytic acidity and increased content of the exchange calcium in the composition of the soil absorbing complex, different qualitative composition of humus, i.e. increase in the humic acid group and aggressive fulvic acid faction 1 and $1 \mathrm{a}$.

4. In the process of soil anthropogenic transformation, composition parameters underwent distinct changes. Anthropogenically altered soil is characterized by soil over-compaction of the genetic horizons with the decrease in the overall porosity which significantly impairs the water-air properties of the soil. The structural condition of mountain-meadow brown soils are characterized by a predominance of granular fine lumpy structure with distinct correct form of aggregates. Under the influence of the anthropogenic factor, structure of the humus-accumulative soil horizon underwent transformation and is characterized by prismoidal structure.

\section{REFERENCES}

[1] Barannyk, A., 2014. Henetyko-heohrafichni osoblyvosti burozemiv polonyn Chornohirs'koho masyvu Ukrayins'kykh Karpat [Genetic and geographical features of brown soils valleys of the Chornohora array of the Ukrainian Carpathians], Materialy XV-oyi Students'koyi Naukovoyi konferentsyy, 6-11.

[2] Barannyk, A., Pozniak, S., 2015. Kyslotno-osnovni vlastyvosti hirs'ko-luchnykh burozemnykh gruntiv Chornohirs'koho masyvu ta yikh transformatsiya u protsesi antropohennoyi diyal'nosti [The acid-base properties of mountain-meadow brown soils of the Chornohora and their transformation in the process of human activities], Naukovi zapysky Ternopil's'koho natsional'noho pedahohichnoho universytetu imeni Volodymyra Hnatyuka. Seriya: Geohrafiya, 1, 33-38.

[3] Barannyk, A., 2016. Osobennosti formirovaniya gumusovogo profilya gorno-lugovoburozemnykh pochv Ukrainskikh Karpat [Features of the formation of the humus profile of the mountain-meadow brown soils of the Chornohora array of the Ukrainian Carpathians], Nauchnyye vedomosti Belgorodskogo gosudarstvennogo universiteta. Yestestvennyye nauki, 25: 103-114. 
[4] Barannyk, A., 2015. Fizychni vlastyvosti gruntiv polonyn Chornohirs'koho masyvu Ukrayins'kykh Karpat [Physical properties of the polonyna's soils of the Chornohora array of the Ukrainian Carpathians], Visnyk Odes'koho natsional'noho universytetu. Seriya: Geohrafichni ta geolohichni nauky, 3(26): 47-59.

[5] Baytsar, A., 2015. Polonyny Ukrayins'kykh Karpat: henezys, poshyrennya ta morfolohiya [Polonyny of the Ukrainian Carpathians: Genesis, morphology and distribution], Konstruktyvna heohrafiya i kartohrafiya: stan, problemy, perspektyvy, 86-90.

[6] Chodorowski, J., Melke, J., Dębicki, R., Bartmiński, P., 2003. Wstęne wyniki badań gleb brunatnych górskich Czarnohory w Karpatach Wschodnich. Gleba w środowisku, 26: 190191. Kongres PTG, Kraków.

[7] Gogolev, I., 1961. K voprosu o genezise burykh lesnykh pochv Karpat [On the genesis of brown forest soils in the Carpathians], Geograficheskiy sbornik, 6: 36-42.

[8] Gogolev, I., 1965. Burye gorno-lesnye pochvy Sovetskikh Karpat [Brown mountain-forest soils of the Soviet Carpathians], Doctoral thesis, Ivan Franko University of Lviv, Lviv: Soviet Academy of Sciences, p. 484.

[9] Kanivets, V.I., 1978. Burozemy v gorno-lugovom poyas Ukrainskikh Karpat i voprosy genezisa pochv burozemnogo tipa [Brown soils in mountain-meadow zone of the Ukrainian Carpathians and questions of genesis of brown soil type], Pochvovedeniye, 8: 108-117.

[10] Kanivets, V.I., 2012. Protsesi gruntotvorennya v burozemno-lisoviy zoni i klasifikatsiya burozemiv [The processes of soil formation in brown soil-forest zone and classification of brown soils], Chernigiv, Vidavnitstvo ChDIEIU, p. 248.

[11] Polupan, M., Velychko, V., Solovey, V., 2006. Soil-ecological zoning of the Carpathian brown soil region. Agriculture, soil science, agricultural chemistry, 10: 16-31.

[12] Pozniak, S., 2002. Problemy stiykosti i zberezhennya gruntovoho pokryvu Ukrayins'kykh Karpat [Problems of stability and conservation of soil of the Ukrainian Carpathians], Mater. Mizhnar. konfer. Hory i lyudy, 2: 442-445.

[13] Skiba, S., Drewnik, M., Drozd, J., 1997. Characteristic of the organic master of ectohumus horizons in the soils of different mountain regions in Poland. The role of humic substances in the ecosystems and in environmental protection, 497-505.

[14] Skiba, S., Drewnik, M., 2003. Mapa gleb obszaru Karpat w granicach Polski. Roczniki Bieszczadzkie, 11: 15-20.

[15] Skiba, S., Pozniak, S., 2006. Grunty pivnichno-zakhidnoyi chastyny chornohirs'koho masyvu Ukrayins'kykh Karpat [Soils of the north-western part of the Chornohora array of the Ukrainian Carpathians], Ekolohiya ta noosferolohiya, 17: 1-2, 105-112.

[16] Skiba S., Szmuc, R., 1998. Pokrywa glebowa Bieszczadów Zachodnich (Historia badań i ich główne kierunki). Roczniki Bieszczadzkie, 7: 131-143. 